\title{
AND THEY SHALL WALK: IDEAL VERSUS REALITY IN POLIO REHABILITATION IN THE UNITED STATES
}

\author{
Daniel J. Wilson
}

Muhlenberg College

\begin{abstract}
This essay explores the significance that rehabilitation physicians and polio patients in the United States put on recovering the ability to walk. Polio often paralyzed or severely weakened the legs of those who contracted the disease. Regaining the ability to walk was thus a significant measure of recovery from the disease. However, walking meant more than the physical act itself. Regaining the ability to walk meant, in a symbolic sense, that one was no longer disabled, that one had again become normal. This attitude was shared by rehabilitation specialists and patients alike. This essay examines this attitude and the cultural values it embodied through a study of the efforts of selected polio survivors to learn to walk again and of the rehabilitation literature that held walking as an ideal. It also explores what happened when polio patients were unable to walk again because of the severity of their paralysis.
\end{abstract}

KEY WORDS: Polio. Poliomyelitis. Rehabilitation. Disability. Paralysis. Wheelchairs.

\section{Y ANDARÁN: LO IDEAL VERSUS LA REALIDAD EN LA REHABILITACIÓN DE LA POLIO EN LOS ESTADOS UNIDOS}

\section{RESUMEN}

En este artículo se analiza la importancia que tiene la recuperación de la capacidad de andar para los especialistas en rehabilitación y los pacientes de polio en los Estados Unidos. La polio iba a menudo acompañada de parálisis o de una grave debilitación de las piernas en aquellas personas que contraían la enfermedad. El recuperar la capacidad de andar era por lo tanto un importante factor indicativo de la recuperación de la enfermedad. Sin embargo, el andar significaba algo más que la simple acción física. El recuperar la movilidad significaba simbólicamente que uno dejaba de ser un minusválido y que volvía a ser una persona normal. Esta postura la compartían tanto los especialistas en rehabilitación como los pacientes. Este artículo analiza esta actitud y los valores culturales derivados de la misma, a través de un estudio sobre los esfuerzos llevados a cabo por un grupo seleccionado de supervivientes de polio para aprender a andar de nuevo así como de un análisis de la literatura sobre la rehabilitación que sostenía que el andar era un ideal. También analiza aquellos casos en que los pacientes de polio no podían volver a andar debido a la gravedad de su parálisis.

PALABRAS CLAVE: Polio. Poliomielitis. Rehabilitación. Minusvalía. Parálisis. Sillas de ruedas. 
One of the iconic images from the polio epidemics of post-World War II America is the March of Dimes poster child. The young polio victim was most often portrayed standing with his or her legs encased in heavy steel and leather braces and leaning on crutches. Viewers were urged to contribute their dimes and dollars to help these youngsters walk again. Although the poliovirus could damage nerves any place in the body, it seemed to have an affinity for the nerves controlling leg muscles, and the inability to walk again came to be the characteristic impairment of polio. Polio's ability to cripple the body, to render a child unable to walk, made it the most feared childhood disease of the twentieth century in the United States. Brenda Serotte, who had polio in 1954 , caught some of the fear associated with polio when she wrote that «Polio's worst curse wasn't death. It was confinement and disability. Confined to a wheelchair. Locked into braces. He will walk with braces and crutches for the rest of his life.» As she wrote, "The blessed walked out of the hospital on their own power; the cursed were pushed out.» ${ }^{1}$ Regaining the ability to walk, even with braces and crutches, became by the 1940s the mark of recovery from polio. Society expected it, physicians, surgeons, and therapists did all they could to make it possible, and polio patients struggled mightily to rise up out of their wheelchairs and walk.

The pressure to walk came from several sources. Socio-cultural expectations of what it meant to recover from a disease such as polio shaped the behaviors of both medical personnel and polio patients. Recovery from paralysis meant regaining mobility, preferably under one's own power and in an upright rather than a sitting position. Standing and walking, no matter how slowly and laboriously, was a sign that one was ready to re-enter the normal world and not remain in the realm of the crippled. Physicians, surgeons, and therapists took each polio patient's inability to walk as a challenge to their professional skill; those who remained dependent on wheelchairs for mobility represented failure in the eyes of many in the medical professions. Polio patients often shared these social and medical values on the importance of walking and worked tirelessly to rise, stand, and move forward under their own power. Those who were unable to walk again because of the damage caused by the virus often felt guilt and shame at their inability to conform to these expectations of what it meant to be cured.

This essay will examine the importance placed on walking as a sign of recovery from polio in post-war America. It will explore the social and medical

1 Serotte, B. (2006), The Fortune Teller's Kiss, Lincoln, University of Nebraska Press, p. 73. Italics in original. 
expectation that being cured of polio meant being able to walk again, as well as the ways in which polio patients internalized these values and attempted to live up to them. It will also consider the physical and psychological challenges of learning to walk again, with or without braces and crutches, and some of the long-term implications for polio survivors of this overemphasis on walking during their rehabilitation. Finally, I will analyze why walking became such a key component of polio rehabilitation and the return of the polio patient to the normal world.

Individuals with obvious physical disabilities, such as the paralyzed limbs characteristic of polio, were typically stigmatized and discriminated against in early twentieth-century America. Persons with disabilities, who deviated from the norm in appearance, were often kept hidden at home, or cared for in the large, grim, state institutions for the crippled. If they sought an education or employment, these individuals with physical disabilities faced both the physical barriers of inaccessible schools and workplaces and the widespread social prejudice against the disabled. There were few facilities designed to provide effective rehabilitation of children and adults with disabilities. The assistive devices of the time, such as wheelchairs and braces, were heavy, ungainly, and as much a hindrance to independence as an aid. Hugh Gallagher has observed that into the 1920s «to be handicapped in some visible way carried with it social opprobrium. The handicapped were kept at home, out of sight, in back bedrooms, by families who felt a mixture of embarrassment and shame about their presence. $\rangle^{2}$ Writing in 1935, Dr. Henry Kessler, one of the leaders in developing modern techniques of rehabilitation, acknowledged that «psychosocial prejudice (...) expressed as an aversion toward the crippled, deformed and disabled» created barriers to the full integration into society for individuals with physical impairments. He acknowledged that modern medical science had considerable power to «improve the defective physically,» and that modern society had adopted a more «humane» attitude toward those with disabilities. However, he also observed that in the 1930s society had «not yet progressed so far as to overcome entirely a reaction of repulsion to all departures from the normal of human kind.» $\rangle^{3}$ The implications for indivi-

2 Gallagher, H.G. (1994), FDR's Splendid Deception, rev. ed., Arlington, VA, Vandamere Press, p. 29.

3 Kessler, H.H. (1935), The Crippled and the Disabled: Rehabilitation of the Physically Handicapped in the United States, New York, Columbia University Press, pp. 13, 22. See also Holland, D. (2006), Franklin D. Roosevelt's Shangri-La: foreshadowing the Independent Living Movement in Warm Springs, Georgia, 1926-1945, Disability and Society, 21, pp. 
duals who had polio was clear. If they were to rejoin society as normal members they needed to reduce the visible markers of their disability as much as possible. For many that meant learning to stand and walk again, no matter how difficult, rather than relying on a wheelchair for mobility.

The importance of walking as a measure of recovery and full reintegration into society was firmly established in the example of Franklin D. Roosevelt. Roosevelt was 39 when he contracted polio in 1921. He had already served in the New York State Senate, as Assistant Secretary of the Navy under Woodrow Wilson, and as the Democratic Party vice-presidential candidate in 1920. From the very beginning of his illness at the family's estate at Campobello Island off the coast of New Brunswick, FDR, his wife, and his close political associate Louis Howe minimized the severity of his illness and the extent of his paralysis. As Hugh Gallagher has argued in his study of Roosevelt and polio, this deception was a necessity if FDR were to have any chance of resuming his political career. ${ }^{4}$ Following his illness, Roosevelt devoted the next several years to his recovery and rehabilitation. Much of his rehabilitation occurred under the care of Dr. Richard Lovett, a Boston physician with considerable experience treating polio patients and his physiotherapy assistants Wilhemine Wright and Kathleen Lake. The focus of their efforts would be Roosevelt's legs, which were almost completely paralyzed. Lovett believed that «a polio patient who could get in and out of a wheelchair and up and down stairs could become independent. $\rangle^{5}$ Walking, or the semblance of walking, was also important to Roosevelt's hopes to restart his political career. Roosevelt indicated as much in a response to Helena Mahoney, a therapist at Warm Springs who had asked what he wanted to be able to do as a result of therapy. FDR replied: «I'll walk without crutches (...) I'll walk into a room without scaring everybody half to death. I'll stand easily enough in front of people so that they'll forget I'm a cripple. $\rangle^{6} \mathrm{He}$ spent many hours slowly wal-

513-535, p. 515; Goffman, E. (1963), Stigma: Notes on the Management of Spoiled Identity, New York, Touchstone, p. 128; MCGowAN, K.R.B. (2005), A Body History of Polio-Related Impairments In the United States: How Individuals' Experiences of their Polio-Related Impairments Responded to Socio-Cultural Shifts in Contemporary American Society, Ph.D. dissertation, Case Western Reserve University, pp. 283-84.

4 Gallagher (1994), pp. XIII-XIV. See also GoldBerg, R.T. (1981), The Making of Franklin D. Roosevelt: Triumph Over Disability, Cambridge, MA, Abt Books, pp. VII-VIII; and WARD, G.C. (1989), A First-Class Temperament: The Emergence of Franklin Roosevelt, New York, Harper \& Row Publishers, p. 579.

5 GoldBerg (1981), pp. 46-47, 73.

6 Gallagher (1994), p. 63; see also WARD (1989), p. 704. 
walking on his crutches down the long drive at the family home in Hyde Park, and later in the warm pool at Warm Springs, but Roosevelt never really regained the use of his legs. With braces, a cane, and strong companions on either side Roosevelt by the mid-1920s managed to give the appearance of walking when it was politically necessary to demonstrate that he had recovered from polio, but walking was always physically and politically risky for him. A very public and humiliating fall could easily have ended FDR's hope of a political comeback. Gallagher has described Roosevelt's walking as «devised for the sake of appearance. It was not in any sense a practical means of locomotion. It was treacherous, slow, and awkward.» Roosevelt could have moved more easily and safely using crutches, but crutches «arouse fear, revulsion, and pity - emotions quite opposite to those a leader would wish to stir.» $\rangle^{7}$ Simply put, Roosevelt could not have led from a wheelchair or propped up on crutches.

A number of scholars have recognized that Roosevelt presented an «ambiguous symbol for disabled Americans. $\rangle^{8}$ He clearly demonstrated that someone with a disability could succeed at a high level through determination and hard work. Roosevelt is the only man elected president four times and he led the United States through both the Great Depression and World War II. Many polio survivors took courage from Roosevelt's example and determined not to let their impairments hold them back. However, once FDR reentered political life and through his two terms as governor of New York and his twelve-year presidency he presented himself as a man who had recovered from polio and as a «recovered cripple. ${ }^{9} \mathrm{He}$ had, for public purposes, regained the use of his legs and learned to walk again. ${ }^{10}$ Roosevelt's decision to disguise the extent of his disability and to present the image of a recovered cripple who had regained the use of his legs and learned to walk again was significant beyond its impact on the politics of the 1930s and 1940s. Roosevelt walking became the standard by which many other polio patients and the country at large judged the success of polio rehabilitation. A man or woman

7 Gallagher (1994), pp. 65-66.

8 Duffy, J. (1987), Franklin Roosevelt: Ambiguous Symbol for Disabled Americans, The Midwest Quarterly, 29, pp. 113-135, p. 113. See also, WILsON, D. (1998), A Crippling Fear: Experiencing Polio in the Era of FDR. Bulletin of the History of Medicine, 72, pp. 464495; and FAIRCHILD, A. (2001), The Polio Narratives: Dialogues with FDR, Bulletin of the History of Medicine, 75, pp. 488-534.

9 DufFy (1987), pp. 120-21.

10 GoldBerg (1981), p. 131. 
walked out of the rehabilitation hospital cured; those who left in wheelchairs were in some measure still disabled and not fully rehabilitated. ${ }^{11}$

Roosevelt and his political coterie were not the only ones to put great importance on regaining the ability to walk. The prevailing opinion in the medical and rehabilitation professions at mid-century also emphasized walking as the primary objective of polio rehabilitation. Sister Elizabeth Kenny, the controversial Australian nurse who revolutionized polio treatment with her hot packs, summarized her attitude in the title of her autobiography, And They Shall Walk. In her more technical books, Kenny stressed her view that patients should be given «every chance of walking without appliances.» ${ }^{12} \mathrm{Dr}$. John Pohl in his book on the Kenny method noted that with proper treatment the «patient literally walks himself back to strength.» He acknowledged that some patients would require continued bracing, but he argued that «a patient with one good leg and one paralyzed leg will walk very well with one or two crutches and will not require any leg brace. A patient with two flail legs will require bracing to one or both but will be able to walk satisfactorily providing that there is good power in the trunk. $\rangle^{13}$ Like Kenny, the orthopedic surgeon Philip Lewin believed that most polio patients could be taught to walk. He was convinced that «persons with very little strength in their legs, hips, abdomen, and back can be taught to walk, to sit down, and to get up from a chair, and, many of them, even to go up and down stairs. The two last named achievements constitute the difference between dependence and independence for the afflicted person.» ${ }^{14}$ The ability to climb stairs was important in an era before the Americans With Disabilities Act (1990) mandated accessible buildings. The surgeon in chief at Warm Springs shared Lewin's conviction that «there are few patients who cannot be taught to walk in one fashion or another. ${ }^{15}$ Dr. Robert Barr, professor of surgery at Harvard University, also believed that «practically every adult and most children with involvement of the lower extremities should be given the opportunity to attempt to walk without a brace.» He was so confident of the skill of orthopedic surgeons as to

11 McGowan (2005), p. 283.

12 Kenny, E. with Ostenso, M. (1943), And They Shall Walk: The Life Story of Sister Elizabeth Kenny, New York, Dodd, Mead \& Company; KenNy, E. (1941), The Treatment of Infantile Paralysis in the Acute Stage, Minneapolis, MN, Bruce Publishing Company, p. 211.

13 PoHL, J.F. in collaboration with KenNy, E. (1943), The Kenny Concept of Infantile Paralysis and Its Treatment, Minneapolis, MN, Bruce Publishing Company, pp. 333-34.

14 LewIN, P. (1941), Infantile Paralysis: Anterior Poliomyelitis, Philadelphia, W.B. Saunders Company, p. 181.

15 Quoted in LEWIN (1941), p. 333. 
declare that «any apparatus which the patient must habitually wear is to that extent an admission of defeat on the part of the surgeon in charge of the case.» ${ }^{16}$ Both orthodox surgeons and unorthodox healers believed that virtually all patients, no matter how seriously involved, could learn to walk, and most of them could learn to do so without braces. But the emphasis usually was on their ability as healer or surgeon to make it happen rather than on the difficult reality patients faced walking with marginal muscle strength or encased in the heavy steel and leather braces of the day.

Doctors and therapists were not the only ones to believe that virtually everyone could be taught to walk again. Polio patients and their families often shared Roosevelt's conviction that you could do anything if you put your mind to it, including walking again. Brenda Serotte, for example, recalls that her therapist Jackie told her that «she had little doubt that I'd soon be walking on my own without any braces whatsoever,» and Serotte admits that she «loved hearing it.» There was no time for pity, no sympathy from the therapist:

«Fight! fight! fight! was, would always be, the polio theme song. There was no such thing as feeling sorry for yourself, crying or saying 'it hurts.' Unless you wanted to be a 'helpless cripple,' synonymous with 'hateful devil,' you fought, you fell, you stretched, you kept working.»

Serotte was «indoctrinated» with the notion that «I'd never achieve the physical mobility I wanted unless I pushed harder than anyone else - in the world. And if I did not reach my goal, it meant that I didn't work hard enough, try my best. ${ }^{17}$ Anne Finger had a similar experience. She remembers that «in some corner of my brain I believed that lie, that with enough grit and determination and hard work we could do anything.») For years she tried to become «a woman with a slight, stiff-legged limp.» She persisted in her belief in spite of «the fact that I have only one functioning muscle in my right leg - a quadriceps I variously describe as 'pathetic' or 'like a strand of overcooked vermicelli.'» Until she was thirty she «forced» herself to «go on long

16 BARR, J.S. (1949), The Management of Poliomyelitis: The Late Stage. In Poliomyelitis: Papers and Discussions Presented at the First International Poliomyelitis Conference, Philadelphia, J.B. Lippincott Company, p. 211. See also GreEN, W.T. (1949), The Management of Poliomyelitis: The Convalescent Stage. In Poliomyelitis: Papers and Discussions Presented at the First International Poliomyelitis Conference, Philadelphia, J.B. Lippincott Company, pp. 180-181.

17 Serotte (2006), pp. 166-168. See also Nudelman, D. and Willingham, D. (1994), Healing the Blues: Drug-Free Psychotherapy for Depression, Pacific Grove, CA, The Boxwood Press, p. 22. 
walks of three, four, sometimes five miles. Perhaps I just wasn't walking far enough. No matter how hard I tried, I believed I just wasn't trying hard enough. ${ }^{18}$ Sometimes the pressure came from the community or family. Jan Little discovered that in her farming community in southern Wisconsin «there was still the pressure to learn to walk. Walking was proof that you had worked hard and overcome your disability. Wheelchairs were associated with old or sick people.» One of her aunts suggested to Little's father that if he would «just set the house on fire, I'd learn to walk so I could get out.» Fortunately the family ignored this advice. Little, who did not learn to walk and relied on a wheelchair for mobility, still thinks about walking: «Down deep, we wonder if we've tried hard enough. After all, we never learned to walk.» ${ }^{19}$

Boys, like girls, shared the view that walking was the ultimate goal. Charles Mee recalls that «the goal was to be a real person who could walk. Walking was the whole deal.» Patients observed others further along in their rehabilitation take their first steps and it kept the dream of walking alive. Mee remembers that «whenever you did see someone begin to walk again — so awkward, fragile, and dangerous an enterprise - it seemed like a miracle.» Mee shared the "common dream» on the ward that «one day we would just get up and walk again, like a real miracle, like making a pilgrimage to Lourdes and being cured by the holy waters there. $\rangle^{20}$ Leonard Kriegel had used a wheelchair during his rehabilitation, but he was able to became, as he said, a «crutchwalker.» $\mathrm{He}$, and most of his ward mates in rehabilitation, believed walking was preferable to relying on a wheelchair:

«I, like almost every boy I lived with during my two-year hospital residency, had absorbed it into the psychic economy of a cripple. The belief that using a wheelchair signified some sort of spiritual surrender had been absorbed into all that I believed made a man a man. $\rangle^{21}$

Whether their muscles would permit walking or not, many, perhaps most, polio patients felt the social and medical pressure to try to learn to walk again.

18 Finger, A. (2006), Elegy for a Disease: A Personal and Cultural History of Polio, New York, St. Martin's Press, pp. 119-20.

19 LitTle, J. (1996), If It Weren't for the Honor-I'd Rather Have Walked: Previously Untold Tales of the Journey to the ADA, Cambridge, MA, Brookline Books, pp. 10-12.

20 MeE, C.L. (1999), A Nearly Normal Life: A Memoir, Boston, Little, Brown and Company, p. 95.

21 Kriegel, L. (1998), Flying Solo: Reimagining Manhood, Courage, and Loss, Boston, Beacon Press, p. 40. 
And as these examples suggest, many internalized that ideal so that it became a personal goal as well.

For most polio patients with leg paralysis learning to walk again was a long and difficult process. Many had spent months in the hospital and rehabilitation facility recovering from the acute attack and slowly rebuilding muscle strength. Following Sister Kenny's arrival in the United States in the early 1940 s most polio patients endured the daily hot packs and passive movement of limbs as therapists worked to discover what muscles had survived and to slowly rebuild muscle strength. Some months into a patient's rehabilitation, doctors and therapists would determine that sufficient strength had returned to attempt to stand and walk again, perhaps aided by braces. For young men and women who had been lying flat in bed or seated in a wheelchair for months, standing was new and scary. Charles Mee began by

«grabbing hold of the horizontal bars that were attached to the wall, pulling myself up out of my wheelchair to my feet and trying to stand there holding on, my midsection swaying from side to side, my knees giving out from time to time, as I learned to bring myself back to equilibrium.»

He had to discover which normal muscles remained and to use «whatever other muscles my body could imagine calling into play to compensate for those that were gone. $»^{22}$ Bentz Plagemann's experience of standing for the first time after months of therapy at Warm Springs was similar:

«My leg brace was finished, and I stood for the first time. It was a frightening experience, even with the crutches provided me, even with people at hand. I felt like a tower constructed of glass blocks, at any moment about to crash and collapse. ${ }^{23}$

But standing was only a prelude to walking.

Learning to take that first step, and the many steps to follow, was often more difficult than standing. Some took their first steps between parallel bars, while others took theirs supported by braces and crutches. However taken, these first tentative steps were both frightening and often exhilarating. Charles Mee took his first steps with considerable assistance. His therapist and

22 MeE (1999), p. 97.

23 Plagemann, B. (1990), An American Past: An Early Autobiography, New York, William Morrow and Company, p. 169. 
«three of her strong-armed assistants sat me up on a cot and swung my steelclad leg over the side. Like Frankenstein. Then the four of them, one holding me around the waist, one under each armpit, one in front waiting for me to fall, hoisted me to my feet and held me there. Like the Marx Brothers. Then they tilted me forward and lifted me up at the waist on my left side only so that the foot came off the floor, and my steel leg swung forward absurdly.»

Mee had taken his first step in months. A few days later, Mee first tried to walk with the assistance of the parallel bars. His wheelchair was moved to the end of the bars and he was brought to a standing position where he could grasp the bars. «My assignment then was to throw myself forward, holding on to the bars, and drag and fling, and scuffle my feet forward a little at a time, and in this way lurch from one end to the other.» Initially he made only a few steps before the assistants retrieved the wheelchair and lowered his «wobbling, exhausted, jellylike body back into the chair» while extolling his achievement. ${ }^{24}$ Like Mee, Edward LeComte also took his first hesitant steps at the parallel bars. One day he managed to «shuffle one foot forward, then the other, one step or two depending on how you count. But with what feebleness, what incredible feebleness and utter weariness.» He knew he should have been «exhilarated at these first steps,» but he was

«only depressed. The road ahead was longer and rougher than my worst imaginings, the mirror at the end of the parallel bars hopelessly distant; and reaching that - sometime in the fifth month — would only be the beginning of the beginning.» ${ }^{25}$

Bill Porteous's first steps in more than six months went somewhat more easily than those of Mee and LeComte. «I walked,» he wrote his wife, «with the slight assistance of a pair of leg braces, abdominal support, and a walker-but nevertheless I did stand up and navigated about 20 feet down the hall and back.» He was «still up in the air» about his achievement when he wrote the letter later in the day. ${ }^{26}$ Whether the first steps came relatively easily or with great difficulty, they were an important milestone in the recovery from polio.

Having taken that all-important first step, the next task was to build strength so that you could walk easily and perhaps unencumbered with braces

24 MEE (1999), pp. 98-99.

25 LeComte, E. (1957), The Long Road Back: The Story of My Encounter with Polio, Boston, Beacon Press, p. 88.

26 Bazzett, T.J. (2007), Love, War \& Polio: The Life and Times of Young Bill Porteous, Reed City, MI, Rathole Books, p. 184. 
and crutches. Raymond Goldman remembered that his walking improved after he was fitted with new braces: «I walked everywhere, slowly and painfully, but I walked; I even learned how to walk up and down the steps by clinging to the banister. $\rangle^{27}$ Charles Mee's first steps with crutches were almost as hesitant as his first steps at the parallel bars, but surrounded by aides he persisted:

«I placed one crutch an inch or two forward and heaved and slid the opposite foot forward, getting it stuck a little sideways, needing my port-side crew to straighten it out, and in this way, after two or three weeks, I was able to scuttle my way crablike on my own down the smooth, polished floors of the corridor outside the therapy room.»

Following a weekend home when, for the first time since polio struck, he could believe that he was not «destined to spend years or even months in the hospital,» Mee worked diligently to improve his walking. He exercised twice daily «to the point of exhaustion, to the moment that my muscles turned to jelly and could not continue. And then I rested until I was ready to go again. I thought of nothing else. $\rangle^{28}$ When she was ready to begin walking, Brenda Serotte remembers that

«every afternoon, Monday to Friday, I was worked: I practiced walking between the parallel bars in the massive gym, back and forth, and then taught how to go up and down a flight of four steps with my braces on.»

Later, after her braces were removed, she repeated the experience. Every day her therapists would stretch her leg muscles and make her do knee bends and then she had to «practice my gait, walking, walking, and more walking. ${ }^{29}$

Regaining the ability to walk was only part of what polio patients had to learn in rehabilitation. If they were going to walk with weakened muscles or on braces and crutches, they would also have to learn to fall safely, since falling was inevitable. The therapists could be merciless in their insistence on learning how to fall without injury. Brenda Serotte remembers being taught that «there was an art to falling, so we fell on purpose, time after time. If we balked, they'd push us back down again, harder.» Initially, Serotte's therapist would help her up, but they eventually «got to the stage where I had to learn

27 Goldman, R.L. (1947), Even the Night, New York, The Macmillan Company, p. 44.

28 MEE (1999), pp. 100, 116.

29 Serotte (2006), p. 166. 
how to rise up by myself from the ground. If I stayed down too long or complained of being tired, she'd nudge me with the tip of her sneaker until I moved.» Jackie, the therapist, told Serotte that she would have to «design a way» that worked for her to rise from the floor. "After falling a million times and practicing endlessly,» Serotte «figured out a technique.» And then she had to practice it over and over again. She recalled that «polios were falling all over the place at Rusk - accidentally and on purpose. Falling was a project we had to master, or they wouldn't let us out. I got an A+.» ${ }^{30}$ Charles Mee's therapist taught him «how to fall, how to twist to one side as I was going down so that I could catch myself with the strength of an arm and roll with the fall.» Learning to fall safely reminded Mee of «football practice, the afternoons we'd spent learning to roll.» ${ }^{31}$ Robert Hall's therapist took a different approach. One morning he told Hall that he would have to walk to physical therapy rather than using his wheelchair. Hall took a few steps in the hallway and then fell down. He wasn't hurt because he had rolled with the fall the way he had seen a friend fall. However, neither the therapist nor the other attendants moved to help Hall up. He got angry at their refusal to help, but he slowly figured out a way to get up with the help of the wall. He started down the corridor again, only to fall after several steps. Once again the staff did not assist Hall and he slowly and laboriously stood up. He «fell down 36 times getting to PT that morning.» When he finally reached the therapy room he «had learned to fall in a relaxed manner and roll with the flow of the fall.» $\mathrm{He}$ had also figured out how to get up off the floor more easily. Initially angry at the therapist's refusal to help him, Hall had gotten over his anger by the time he entered the therapy room. He replaced anger with «the feeling of accomplishment. I knew how to fall and I had gotten there. No one else could have given that to me. I had done it for myself.» ${ }^{32}$ Leonard Kriegel's lessons in falling were more protracted. Although he wanted to please his therapist, the eleven-yearold Kriegel could not bring himself to fall: "when my therapist commanded me to fall, I cringed. The prospect of falling terrified me.» $\mathrm{He}$ knew he wouldn't be injured falling on the thick floor mats, but he couldn't bring himself to let go and just fall. His therapist «pleaded, ridiculed, cajoled, threatened, bullied,» but Kriegel couldn't fall. Then, after «a month of struggle» the «terror simply evaporated,» and he let go and fell on to the mat. He had

\footnotetext{
30 SerotTe (2006), pp. 167-68, 171-72.

31 MeE (1999), p. 102.

32 Hall, R.F. (1990), Through the Storm: A Polio Story, St. Cloud, MN, North Star Press, pp. 96-97.
} 
«simply been worn down into letting go, like a boxer in whose eyes one recognizes not the flicker of defeat - that issue never having been in doubt - but the acceptance of defeat (...) I found myself quite suddenly faced with a necessary fall -a fall into life. $\rangle^{33}$

Having mastered the skill of falling as well as the skill of walking, polio patients were ready to walk out of the hospital. As Turnley Walker wrote in his aptly named memoir Rise Up and Walk,

"you have won the first big victory. You can walk alone. You can leave the hospital where you have suffered through the terrible beginning stages of the disease, and have climbed upward to the doorway, inch by inch.. ${ }^{34}$

For some families walking by itself was not sufficient. They wanted their son or daughter to walk normally, not with the peculiar rocking gait of many polio survivors. For example, Brenda Serotte's mother asked Dr. Howard Rusk, one of the leading figures in polio rehabilitation, whether her daughter would ever «walk normally.» She wanted to know if Brenda would «again be exactly the same as before? The same as others? $» »^{35}$ Dr. Rusk assured her that her daughter was «already normal,» but as for the walking he could only «hope that this lovely girl will go very far indeed.» Even after Serotte was discharged from the Rusk Institute her mother wasn't satisfied with her walking. In spite of the family's precarious economic situation, her mother wanted her to "walk well, not just 'okay,'» and she hired a private therapist to come weekly to supervise Brenda's exercises and walking. Mrs. Serotte also dragged her reluctant daughter to a series of specialists in search of something that would enable Brenda to walk normally. Finally one of physicians told Mrs. Serotte that her daughter was «fine as she is; she may even walk better one day. But there are no miracles! Accept it!» Mrs. Serotte may not have fully accepted it, but this was the last specialist she consulted. ${ }^{36}$

Sometimes, in spite of the best efforts of therapists and surgeons, walking simply was not possible because of the extent of the paralysis. Not enough muscle strength remained even if the legs were encased in braces and crutches were used. However, the decision to rely on a wheelchair for mobility

33 Kriegel, L. (1991), Falling into Life, San Francisco, North Point Press, pp. 10, 12-13.

34 Walker, T. (1950), Rise Up and Walk, New York, E.P. Dutton, p. 93.

35 SERotTe (2006), p. 170. On the gait of polio survivors, see SiEBERS, T. (1998), My Withered Limb, Michigan Quarterly Review, 37, pp. 196-205.

36 SEROTTE (2006), pp. 170, 190-91. 
was difficult and one that family members sometimes resisted longer than the polio patients themselves. Jan Little, as noted earlier, felt the community pressure to walk, to become normal, but she lacked the muscles to make it possible. Her mother drove her twenty miles three times a week to work with a therapist in hopes of being able to walk again. Miss Wolfgram, the therapist, would «prop me up on braces that reached to my waist, re-enforced by a corset that reached to my armpits and we would practice walking.» The result was not encouraging. Usually, Little «imitated a tree.» She would «sway back and forth a few frantic moments, then crash to the ground, maintaining a straight position» as she fell. As Little notes, «nothing worked - except me and Miss Wolfgram.» Little and her family ultimately decided that it made more sense to get on with life in a wheelchair than to pursue an impossible dream. ${ }^{37}$

Allen Lee attempted to learn to walk while at Warm Springs. He was fitted with new braces and he had the feeling that he «sat in the braces even when I was standing upright.» In addition to the leg braces, he wore a corset to keep his torso from bending. His crutches also had braces to keep his arms straight. Lee thought that «this must be how an inanimate object feels,» or perhaps «a telephone pole, not anchored into the earth, and likely to fall in any direction.» Two people kept him from bending forward and when he tried to lift his legs it was «like trying to lift heavy objects with rubber bands.» He was able to keep his balance, but his feet seemed firmly planted on the ground. When he tried walking it was «no longer a habit. I had to think of every move I tried to make. Every day for four months I struggled. And I made no progress. ${ }^{38}$ Finally, the head physician told him that Warm Springs had done all it could. Lee was not surprised as his long struggle had made it «more and more apparent that it would be with the greatest of difficulty» that he would ever walk again. «Slowly, slowly, high hopes had been pushed into a far corner» of his mind, but even then, «the hopes died a lingering death.» Even as he accepted the inevitable, he dreaded the task of telling his family and friends that he would need to use a wheelchair for the rest of his life: «I could hear Mother's voice saying, as she had before, 'I cannot believe my boy will not walk again.'» He knew that «it would be far harder to adjust my family and my friends to my condition than to adjust myself to being crippled always. $\rangle^{39}$ Paul Reitmeir's family also found it difficult to adjust to his decision

37 LitTle (1996), pp. 11-12.

38 LeE, A.V. (1948), My Soul More Bent, Minneapolis, MN, Augsburg Publishing House, pp. 48-49.

39 LEE (1948), pp. 56-57. 
to use a wheelchair rather than to continue to struggle to walk. Even though he knows he made the right decision, he still «had a lot of guilt.» As he noted, the attitude in the late forties was that if you could walk, «you're going to be normal then. You're not going to be quote [a] 'cripple.' $\rangle^{40}$

Several of the patients in Kathryn McGowan's study of polio survivors recalled the resistance they faced when they gave up walking for a wheelchair. One participant remembered that her father «used to bring up how Franklin Roosevelt could stand there and talk and hang on to this thing and I should try to be like him.» Her parents and therapists implied that she didn't try hard enough:

«For a while, I still thought I was gonna walk. I mean, I did what they wanted me to do, but I didn't do it willingly (...) I thought I would automatically walk. Plus I guess I wanted to walk because everybody else did.» ${ }^{41}$

Another informant made her decision not to walk at age 17 after conferring with her surgeon. After the surgeon told her he would not fuse her spine because it wouldn't help her walk and might impair her breathing, she «realized that I had to give up that hope that I'm going to walk. That I have to realize that I'm going to be in a wheelchair, but it's going to be okay. I can live this way.» Several years later with her doctor's permission she gave up her braces since she didn't need them in the wheelchair. ${ }^{42} \mathrm{~A}$ third informant told McGowan that she found the therapists' insistence that she learn to walk «so abusive, $\gg$ since it was clear that was not possible in her case. ${ }^{43}$ In each instance McGowan's participants had felt pressure from family or medical professionals to try harder to walk, and in each instance they resisted because they recognized that task was impossible or not worth the extreme effort for limited mobility.

When polio survivors from the post-war epidemics began to experience post-polio syndrome three to four decades after their acute disease, many who had managed to walk in some fashion all those years found, much to their distress, that the new muscle weakness they experienced meant that they had to return to using a wheelchair. Some reported that «they experienced a profound sense of physical and social isolation when using a wheelchair.» One of

\footnotetext{
40 Paul Reitmeir, interview with Daniel J. Wilson, Bethlehem, PA, August 2, 2002.

41 Annette in McGowaN (2005), p. 570.

42 Janet in McGowan (2005), pp. 570-71.

43 Mary in MCGowan (2005), p. 572.
} 
McGowan's participants told her that «I sort of feel like I did when I had polio. I can't get around. Thank God I had all those years in between where I could walk and get around and feel normal.» ${ }^{44}$ As a young man Leonard Kriegel had worked very hard to become a «crutchwalker,» to avoid reliance on a wheelchair. In his youth he believed that «using a wheelchair signified some sort of spiritual surrender.» But in his fifties, Kriegel found that aging and the wear and tear on his body from forty years of walking on braces and crutches necessitated that he return to using a wheelchair. Although he has lingering doubts that perhaps he moved to the wheelchair a few years before he really needed to, Kriegel discovered that «getting back into the wheelchair was not the spiritual death» he had feared. He was proud of having walked for forty years, but now he was ready to say "To hell with it» and return to using the chair. ${ }^{45}$ Justine Guckin lost some friends when she returned to using a wheelchair because «their view of my polio is, 'Well, why are you giving up, and why are you going in a wheelchair? You used to be such a fighter.» Guckin, however, remains firmly convinced that she is still the same person she always was even though now she relies on a wheelchair for mobility. ${ }^{46}$ Although the changes in accessibility brought about by the Americans With Disabilities Act since 1990 have made it easier to move about in a wheelchair, the attitude that walking is better is still common among polio survivors, their families and their friends.

Running through the accounts of polio survivors learning to overcome their paralysis and walk again was the desire, often shared with family, friends, and therapists, to appear «normal» by moving about the world from an upright, standing position, even if braced and using crutches. As Kathryn McGowan has written, «when the American public wanted to bring their people back to mainstream society, they wanted 'cured cripples,' not bodies that appeared visibly altered by polio.» Nor did they want bodies reliant on wheelchairs for mobility. Becoming «a 'cured cripple' meant emulating FDR,, and that meant standing and walking, or at least simulating walking. ${ }^{47}$ Marilyn Phillips in her study of the classic American injunction to individuals with disabilities - Try Harder - has explored the ambivalence that such individuals often have regarding «capitulating to societal pressure to achieve

44 McGowan (2005), p. 639.

45 KRIEGEL (1998), pp. 40, 44-45.

46 Silver, J. and Wilson, D. (2007), Polio Voices: An Oral History from the American Polio Epidemics and Worldwide Eradication Efforts, Westport, CT, Praeger, pp. 133-34.

47 McGowan (2005), p. 283. 
form and function normality.» For some informants in her study, that meant electing «not to spend time and energy learning how to walk again.» Others, however, chose to persevere in their effort to walk, «Because they respect you more if you can 'stand up' to them!» Those who sought «success-asnormalization» often chose to affiliate with «normals» and to disaffiliate with «those perceived to acquiesce to the 'cripple role.' ${ }^{48}$ Lennard Davis has argued that «disability presents itself to 'normal' people through two main modalities - function and appearance.» For polio survivors, standing and walking, even with crutches and with difficulty, meant they were less disabled, more normal, than those reliant on wheelchairs. Davis also argues that «the person with disabilities is visualized, brought into a field of vision, and seen as a disabled person.» Sitting in a wheelchair instantly marks one as disabled in ways that standing and walking, even with braces and crutches, do not. ${ }^{49}$ McGowan, Phillips, and Davis all recognized that these standards of normality are social and cultural standards not absolute ones, but they were no less coercive in their application.

By the 1940s physical therapy and surgery ensured that many polio patients with lower limb involvement could regain the ability to walk, sometimes unaided, often with braces and crutches. Inspired by the example of President Roosevelt, the medical profession, polio patients, their families and friends, all subscribed to the notion that walking, no matter how difficult, was the surest sign that one had recovered from polio, that one would not be a permanent cripple. Most polio patients who had any possibility of walking made the effort; they responded, often enthusiastically, to the injunction to «try harder.» Where sufficient muscle strength remained, or where the brace makers were effective, polio survivors learned to stand up and walk again. But, as we have seen, that was not always possible. Some polio survivors lacked the minimum muscle strength necessary to walk, or, in other cases, walking took so much energy with only minimal success, that a wheelchair became the only realistic option for mobility. Many of those who chose to rely on wheelchairs felt guilty that they had somehow failed, that they had not tried hard enough. In addition to their physical impairments, some polio survivors carried a psychological burden because of their failure to conform to social and cultural norms.

48 PhILliPS, M.J. (1985), 'Try Harder': The Experience of Disability and the Dilemma of Normalization, The Social Science Journal, 22, pp. 45-57, p. 50. See also SIEBERS (1998), pp. 199-200.

49 Davis, L.J. (1995), Enforcing Normalcy: Disability, Deafness and the Body, New York, Verso, pp. 11-12. 
In the era before the Americans with Disabilities Act began to create a more accessible physical environment, walking and the ability to climb stairs had some clear advantages over relying on a wheelchair for mobility. However, many polio survivors who depended on wheelchairs successfully pursued an education, found and kept rewarding jobs, dated, married, and had children. Although they may have wished to walk, to conform to the social norms, they found ways to successfully challenge those norms from a sitting position. ${ }^{50}$ Walking may have been the ideal, even the norm, but when it clearly wasn't possible or functional, polio survivors generally adapted to the wheelchair and got on with their lives. Certainly the achievements of those who rose up and walked, often with great difficulty and at substantial physical cost, should be remembered and celebrated. But no less worthy of commemoration and celebration are those polio survivors who took on the world from a sitting position.

Fecha de recepción: 21 de enero de 2008.

Fecha de aceptación: 26 de enero de 2009.

50 WiLson, D.J. (2005), Living with Polio: The Epidemic and Its Survivors, Chicago, University of Chicago Press, pp. 169-227. 